\title{
Reflections on the Readiness of the University of South Africa Eastern Cape Region for the Deployment of E-Learning
}

\author{
Thunyelwa Holomisa \\ Department of Tuition and Facilitation of Learning, University of South Africa \\ Email: holomt@unisa.ac.za \\ Luyanda Dube \\ Department of Information Science, University of South Africa \\ Email: dubel@unisa.ac.za
}

\section{Doi:10.5901/mjss.2014.v5n14p290}

\section{Abstract}

An electronic learning (e-learning) readiness entails a complex, involving, integrated, inclusive and continuous process of identifying underlying factors likely to impact negatively on the deployment of e-learning. In essence, assessing e-learning readiness enables organisations to analyse critical issues including capability and connectivity because those using technologies tend to carry over predominant styles rather than developing new formats that exploit the unique features of the medium. The University of South Africa (UNISA) is rolling out an e-learning initiative to all undergraduate modules starting from 2013. In line with open distance learning (ODL) principles, UNISA established Regional Learning Service Centres, which are not simply there for administrative convenience but are there as academic support centres meant to facilitate learning. The purpose of this study is to examine readiness of Regional Learning Centres in terms of their capability to implement e-learning as the dominant paradigm in the facilitation of learning. A basic interpretative qualitative research design was used for this study. Data was collected through document analysis, questionnaires and interviews. Overall, the results highlight that when it comes to the practicalities of implementing e-learning there is lack of clarity about the meaning of the idea, what it involves or implies and the description of its exact parameters. The study recommends that the University should establish synergy between new initiatives as well as students' realities, staff capability and regional infrastructure and socio-economic conditions.

Keywords: - e-learning; tuition; teaching; learning; e-learning preparedness; and UNISA regional offices

\section{Introduction}

An electronic learning (e-learning) preparedness or readiness entails a complex, involving, integrated, inclusive and continuous process of identifying underlying factors likely to impact negatively on the deployment of e-learning (Carry \& Willis, 2001; Clegg, Konrad \& Tan, 2000; Kaur \& Abas, 2004; Lopez, 2007). In essence, assessing e-learning readiness enables organisations to analyse issues related to connectivity, capability, culture and content (Aydin \& Tasci, 2005; Schreurs, Sammour \& Ehlers, nd.; So \& Swatman, 2006; Ssemugabi \& De Villiers, 2010; Tucker, 2007; Tubaishat \& Lansari, 2010-2011; Watkins, Leigh \& Triner, 2004). These are issues that are critical to the successful implementation of e-learning.

The determination of e-learning readiness is critical because e-leaning involves the deployment of institutional financial resources (Aydin \& Tasci, 2005; Buabeng-Andoh, 2012; Carry \& Willis, 2001; Clegg, Konrad \& Tan, 2000; Curran, 2004; Saekow \& Samson, 2011; Schreurs, Sammour \& Ehlers, nd.; So \& Swatman, 2006; Ssemugabi \& De Villiers, 2010; Tubaishat. \& Lansari, 2010-2011). Evidently, in the era of economic volatility no institution would want to commit its resources to an initiative that is destined to be unsuccessful. This is the reason why e-readiness analysis should be executed before the organization deploy e-learning.

\section{The Problem Statement}

UNISA's strategic drive to adopt a fully fledged online learning model will be actualised in 2013. In essence the benefits of implementing e-learning are widely documented. However, various authors counsel that if e-learning is adopted without careful planning it is most likely end with failure (Abu-Hassan-Assari, 2005; Agboola, nd.; Ahmed, 2008; De Villiers, 2005; 
Dyson, 2004; Engelbrecht, 2003; Faheeg, 2011; Granic, Glavinic \& Stankov, 2004; Hall \& Snider, 2000; Higgins, nd.; Tubaishat. \& Lansari, 2010-2011; Watkins, Leigh \& Triner, 2004). To avert this, they advise that any major e-learning innovation requires an up-front analysis of the preparedness of an institution and its constituencies.

The UNISA Eastern Cape region comprises of a hub (head office) in East London and two Regional Service Centres, Mthatha to the north and Port Elizabeth in the south. The Eastern Cape Province is renowned for adverse poverty and underdevelopment. Due to the socio-economic situation in the province, students mainly come from disadvantaged backgrounds in terms of computer knowledge, skills, affordability and accessibility. They are likely to rely heavily on the regional centre for support with the exploitation of computer mediated learning systems. That is why it is pertinent that staff in the regional centres need to have capability to provide facilitatory and support services that will advance the University agenda. Given the role of regional centres, it is important for the University to determine, understand and appreciate critical factors related to capacity, attitudes, infrastructure and connectivity. Therefore, it is imperative for UNISA to consider addressing both positive and negative attitudes, perceptions, questions, feelings, thoughts and emotions of staff in regional offices. The effect of disregarding the readiness of regional offices might be dire. It might reflect lack of synergy between University structures, systems and processes. This might negate or undermine not only e-learning deployment and uptake, but also institutional goals and objectives (Kaur and Abas 2004). It is in this regard that this paper seeks to examine the readiness of regional ICT infrastructure and staff competency to support the increase in demand due to e-learning initiatives.

The main aim of the study is to assess readiness of the Eastern Cape Regional offices towards e-learning. This aim was underpinned by the following research questions:

1. To what extent is the Eastern Cape regional infrastructure compatible with Unisa systems for e-learning?

2. To what extent are networks systems in the Region compliant to e-learning support?

3. To what extent is the regional staff prepared to facilitate and support the e-learning model?

4. To what extent is the regional management committed to executing support for e-learning?

\section{Literature Review}

E-learning as a medium of instruction in university education and in particular distance education has evolved significantly over the years. In South Africa, the use of information communication technologies (ICT's) is a serious component of the higher education agenda (CHE Report, 2006-2007). There is evidence that a number of higher education institutions in the country are using e-learning to enhance and extend tuition (Unwin, 2008) and strengthen social change (van Audenhove, 1999). E-learning has benefits that have been recognised all over the world. For instance, e-learning has the capacity to enable the institution to deliver a responsive, up-to-date and seamless learning experience (Abu-HassanAssari, 2005; Agboola, nd.; Ahmed, 2008; De Villiers, 2005; Dyson, 2004; Engelbrecht, 2003; Faheeg, 2011; Granic, Glavinic \& Stankov, 2004; Ssemugabi \& De Villiers, 2010; Tucker, 2007; Tubaishat \& Lansari, 2010-2011; Watkins, Leigh \& Triner, 2004).

Similarly, through e-learning academic tuition is executed with greater efficiency and at a lower cost. It also offers opportunities for sharing information, enhancing just-in-time accessibility (So \& Swatman, 2006), reducing costs (AbuHassan-Assari, 2005; Engelbrecht, 2003), fostering national and international networks, enhancing the quality of traditional education, promoting greater interactivity, maximising collaboration (Abu-Hassan-Assari, 2005; Karmakar \& Wahid, nd.), as well as offering flexibility and autonomy between stakeholders (Kaur \& Abas, 2004; So \& Swatman, 2006). E-learning is also renowned for making education accessible to learners particularly in rural areas, who otherwise would not have an opportunity (Unwin, 2008). Notwithstanding the benefits, it has emerged in the literature that not all elearning initiatives implemented by various institutions have been successful because of low uptake by users (Aydin \& Tasci, 2005; Kaur \& Abas, 2004; Karmakar \& Wahid, nd.; Saekow \& Samson, 2011; Schreurs, Sammour \& Ehlers, nd.; So \& Swatman 2006; Ssemugabi \& De Villiers, 2010; Tucker, 2007; Tubaishat. \& Lansari, 2010-2011; Watkins, Leigh \& Triner, 2004). It is against this background that this paper sought to conduct an upfront analysis of the preparedness of the Eastern Cape Regional Learning Centre in terms of its capability to implement e-learning as the dominant paradigm in the facilitation of learning.

\section{The UNISA Context}

The University of South Africa (UNISA) is the only dedicated open distance learning (ODL) institution in South Africa with around 300000 (in 2012) registered students within and beyond the borders of South Africa. The service ethos of UNISA is embodied in the mission statement of being "the African University in service of humanity". UNISA prides itself by 
providing access and "promote African thought, interest and epistemologies" to students irrespective of where they are (UNISA Revised Curriculum Policy, 2012). This implies servicing diversified learner communities in national and international contexts and specifically responding to African needs. To fulfil its mandate the university had to decentralise its service points by establishing seven regional centres in various provinces of South Africa and in Ethiopia (refer to table 1). The fundamental mandate of the regional centres is to provide a positive learning experience for students and to facilitate their success by providing academic support services (UNISA Regional Model, 2012).

Table 1. UNISA Regional centres

\begin{tabular}{|l|l|l|}
\hline \multicolumn{1}{|c|}{ Region } & \multicolumn{1}{|c|}{ City/Hub } & \multicolumn{1}{c|}{ Geographic spread (provinces and neighbouring countries) } \\
\hline Gauteng & Pretoria & Gauteng Province \\
\hline KwaZulu Natal & Durban & KwaZulu-Natal Province \\
\hline Western Cape & Cape Town & Western Cape Province and part of the Northern Cape and Namibia \\
\hline Limpopo & Polokwane & Limpopo Province and Zimbabwe \\
\hline Eastern Cape & East London & Eastern Cape Province \\
\hline Mpumalanga & Nelspruit & Mpumalanga Province, Swaziland and Mozambique \\
\hline Midlands & Rustenburg & North West, Free State and Northern Cape Provinces \\
\hline
\end{tabular}

Source: Adapted from the UNISA Regional Model, 2012

Pityana (2005) contend that regional centres are not simply there for administrative convenience, they are there to facilitate learning, by putting at the disposal of students, services like tutorials, library and information systems, counselling and advisory services, computer access and a range of assistive programmes for learners. He further argues that the imperatives of UNISA as an ODL institution is to enhance learner support by extending reach and cutting "distance" from distance education to ensure that distance education can be intellectually exciting, cognitively challenging and rewarding in its outcomes as any other form of higher education study. From 2013 the university is rolling-out elearning as part of the ODL implementation plan of transforming to a fully digitised transactional environment.

The envisaged digitisation entails tuition buttressed by robust, effective and integrated ICT applications (UNISA Organisational Achitecture Report, 2012). The envisaged e-learning model will be built into existing Learning Management System (LMS) called myUnisa. It is through this LMS that interaction between student-to-student, studentto-lecturer and student-to-tutor and vice versa has been made possible (Kinuthia \& Dagada, 2006; UNISA Tutor Model 2012). Czerniewicz (ed) has however highlighted Unisa's diverse student base with very low ICT skills and access to ICT infrastructure as a challenge (2007). By implication the success of the e-learning implementation will largely depend on the competent support and facilitatory role of all relevant stakeholders including regional centres. Because of the dispersed, solitary and diverse nature of the ODL student, a new initiative like e-learning can usually cause uncertainty and uneasiness. That is why it is critical for regional offices to understand and appreciate their levels of readiness or lack thereof.

To service the massive numbers of students the University relies heavily on the tutor system. The use of tutors is not unique to UNISA as Kinuthia and Dagada (2006) state that universities usually employ tutors as a support service that augments classroom teaching and learning. The introduction of e-learning meant the transformation of physical tutorial services into virtual or e-tutorial services. These e-tutorials will be conducted via myUnisa.

The thesis of the paper is that the regional offices are supposed to act as mediators or as a first port of call between the students and tutors and students and the University. Although the article recognises that the Eastern Cape Regional offices provide services to student from diverse backgrounds in terms of information communication technology skills, infrastructure and other socio-economic factors it does not want to prempt that e-services in the region will be hampered.

\section{Research Methodology}

The study adopted a quantitative paradigm and obtained data through questionnaires and document analysis. The study targeted the total population of permanent staff ranging from managers to technicians from East London, Port Elizabeth and Mthatha. Although questionnaires were sent to all members of staff (32), only 25 responded. In addition to this, institutional documents and related literature were analysed. Furthermore, the researchers drew on their experiences and exposure as UNISA employees. The results of a study that employs a basic analytical and interpretive design are 
interpretative and descriptive as is the case with this research.

\section{Findings and Discussion}

Out of the 32 respondents that were targeted only $25(78 \%)$ returned the questionnaire. As the study targeted the three Eastern Cape regional offices the response rate was as follows East London (44\%), Port Elizabeth (16\%) and Umtata (40\%). From these offices different sections recorded different response levels. The highest number of respondents $52 \%$ was from the Registration unit, followed by 20\% from Support Services (Marketing, Finance, Student Funding and Centre Coordinators). Units that had few respondents were Facilitation of Learning with $16 \%$, Counselling $8 \%$ and Computer Laboratories $4 \%$.

\subsection{Biographical information}

The intention of soliciting information from respondents about gender, age and level of education was to determine whether these variables will make any significant difference in the level of readiness of respondents. Thus, a cross tabulation was done in analysis to establish if there is any correlation between staff demographic characteristics (gender, age, education and employment level) and the perception on readiness in terms of the different variables.

The biographical details presented below reflect that out of the 25 respondents, $24 \%$ were females and $76 \%$ were males. The age groups of the respondents ranges between 21 years to above 51 years. Summarily, only two respondents (8\%) were in the bracket of 21-30 years, whereas 12 (48\%) were between 31-40 years, six (24\%) were between $41-50$ and five (20\%) were above 51 years of age. The qualification of most respondents is a Bachelor's degree $24 \%$ and an Honours degree 24\%. The respondents with Masters degree were 16\% and the "other" category consisted of staff members with Senior Certificate 20\%, and lastly, the Diploma category were 16\%. Besides the biographical information, questions asked seek to solicit information on policy stipulations, network systems, infrastructure, staff aptitude and attitude as well as anticipated challenges and opportunities brought by e-learning.

\subsection{Institutional policies}

UNISA as an institution has a battery of policies that inform major institutional functionalities including tuition. Based on this presumption questions were asked to assess the extent to which employees in the Eastern Cape region are familiar with policy dictates related to the implementation of e-learning.

Table 2. Breakdown of staff awareness and familiarity with policy prescripts

\begin{tabular}{|c|c|c|c|c|c|c|c|}
\hline & Statement & Services & Strongly Disagre & Disagree & Not Sur & Agree & rongly Agree \\
\hline \multirow{5}{*}{2.1} & \multirow{5}{*}{$\begin{array}{l}\text { Staff is familiar with institutional } \\
\text { policies }\end{array}$} & Registration & $7.7 \%$ & $15.4 \%$ & $38.5 \%$ & $23.1 \%$ & $15.4 \%$ \\
\hline & & Counselling & $0 \%$ & $20 \%$ & $60 \%$ & $20 \%$ & $0 \%$ \\
\hline & & Instructional Support \& Services & $0 \%$ & $0 \%$ & $100 \%$ & $0 \%$ & $0 \%$ \\
\hline & & Computer Lab & $0 \%$ & $0 \%$ & $60 \%$ & $40 \%$ & $0 \%$ \\
\hline & & Support Services & $4 \%$ & $16 \%$ & $48 \%$ & $24 \%$ & $8 \%$ \\
\hline
\end{tabular}

As respondents were drawn from different sections it is interesting to note the discrepancy between the different units. Observable is that the majority of respondents chose the neutral category of being not sure of their familiarity or lack thereof with institutional policies. Stemming from the observable indeterminate state about the familiarity or lack thereof, a deduction could be made that the familiarity with policies is low, because this is something that an individual would rightly know or do not know, there is no doubt about it. Although this maybe branded controversial the paper takes a stand that familiarity with an entity is absolute, either it is there or is not. Nonetheless, the paper underscores the importance of knowing institutional policies as they inform the strategic direction and overall functionalities. 
Table 3. Awareness about e-learnng policy: managers versus staff

\begin{tabular}{|c|c|}
\hline Managers & Staff \\
\hline Are aware that the policy exists. & $\begin{array}{l}\text { Most respondents indicated they are not sure about the } \\
\text { existence of a policy. }\end{array}$ \\
\hline $\begin{array}{l}\text { Have not actually interrogated the policy to determine its focus, } \\
\text { implications for the regions and whether the role played by } \\
\text { regions will be affected. }\end{array}$ & $\begin{array}{l}\text { Even the few who knew about it do not know what it } \\
\text { entails and what it means for the practice in the regions. }\end{array}$ \\
\hline
\end{tabular}

Comparatively, the responses above firstly show that managers as people who are supposed to provide strategic direction and focus are aware of the existence of related policies. On the other hand, most staff gave an indication of an indeterminate answer about the existence of related policy. Secondly, both groups conceded that they have not interrogated or familiarised themselves with the policy dictates to determine implications for the regions.

\subsection{Network systems and infrastructure}

Given that e-learning entails technology-enabled learning (Assari, 2005), network/ technology infrastructure that enables connectivity is of essence. As indicated earlier based on its ODL nature UNISA created regional offices with the intent of decentralising services ensuring wide participation. E-learning relies heavily on the availability of computers and other related infrastructure and resources. Table 4 depicts the number of support staff and available computers vis-à-vis the number of registered students in the Eastern Cape region. The respondents were asked if the number of computers in the centres is enough to service the number of students who regularly use these centres. There was a significant difference in respondents in the three centres with $41 \%$ from Port Elizabeth agreeing that computers are enough whereas a lesser number in East London 28\% and in Mthatha 20\% agreed. Overall, staff agreed that computers were insufficient to cater for registered students.

Table 4. Human and computers resources

\begin{tabular}{|l|c|c|c|}
\hline \multicolumn{1}{|c|}{ Centre } & No of permanent staff & No of students & No of Computers \\
\hline East London & 15 & 7715 & 15 \\
\hline Mthatha & 13 & 7621 & 34 \\
\hline Port Elizabeth & 5 & 6024 & 14 \\
\hline Grand Total & 32 & 21360 & 63 \\
\hline
\end{tabular}

Source: UNISA Department of Information and Strategic Analysis (DISA), 2012

The deduction that can be made from Table 4 is that there is no correlation between the number of human and computer resources versus the number of students. Given the socio-economic realities of the Eastern Cape Province it is somehow concerning that regional offices have limited numbers of computers and staff members. The situation could be worsened by the fact that not all these computers are likely to be in a good working condition everytime.

In a status report on ICTs and higher education in Africa Czerniewicz (2007), alluded that the amount of bandwidth a country has determines the quality and speed at which information can travel. It is of utmost importance that the connectivity and compatibility between systems in the main campus and the regions is well planned and prioritised. Otherwise lack of incompatibility could render regions incompetent and ineffective. It is in this regard the respondents were asked to comment on the perceived efficacy of network connectivity or lack thereof. In terms of speed of access to Internet and bandwidth size, there was a significant difference in staff perception in different centres. Whilst $50 \%$ of staff in Port Elizabeth and 50\% Mthatha disagreed that the network system is fast and has adequate bandwidth size, $40 \%$ of staff in East London shared the same sentiments. Suprisingly, it was also highlighted by some respondents that not all computers have internet connectivity.

With regard to network reliability, $55 \%$ of East London staff had positive responses. Port Elizabeth and Mthatha staff unanimously alluded to the fact that the network is unreliable. Suprisingly, one would have thought East London and Port Elizabeth somehow have similar experiences because of the issue of urbanisation versus the rural dispensation 
apparent in Mthatha. Both East London and Port Elizabeth are cities that are fairly developed compared to Mthatha. Despite being urban centres East London and Port Elizabeth showed a significant difference between the reliability of network and connectivity. Mthatha which is largely rural with evident afflictions related to underdevelopment such as indefinite electricity blackouts has negative responses.

Linked to the network connectivity is the wireless networking that has developed rampantly over the years. Notably, a few respondents from both East London and Port Elizabeth acknowledged the availability of wireless network in their offices. Apparently, in Mthatha wireless networking is still in the pipeline, it was not available when the study was conducted. In terms of the reliability of electricity supply, East London staff mostly agreed that it is reliable and maintained. The responses of Port Elizabeth and Mthatha staff mostly disagreed that electricity is reliable. In addition, Mthatha staff disagreed that the region has adequate maintenance capacity to enhance performance and most staff in Port Elizabeth and East London were not sure.

\subsection{Staff capacity}

Training of staff has been identified as an important variable in assessing readiness for e-learning. The responses are tabulated according to pernommes levels. The intention was to determine whether there is any observable difference between staff aptitude on the different levels of seniority. Whilst most staff at managerial level (P6, P7) mostly disagreed that they have been trained to assist with students' queries, the majority in lower levels (P8, P10 \& other) were not sure whether they have been trained or not. Notable, are discrepancies among junior staff members, whereas P8 and P10 were not sure about the training aspects P9, took a stand similar to P6 staff at managerial level who downrightly indicated that there was no training received.

Table 5. Staff aptitude and attitude

\begin{tabular}{|c|c|c|c|c|c|c|c|}
\hline & Statement & Level & $\begin{array}{l}\text { Strongly } \\
\text { Disagree }\end{array}$ & Disagree & $\begin{array}{l}\text { Not } \\
\text { Sure }\end{array}$ & Agree & $\begin{array}{c}\text { Strongly } \\
\text { Agree }\end{array}$ \\
\hline \multirow{6}{*}{5.1} & \multirow{6}{*}{ Staff has been trained to facilitate student queries } & P6 & $0 \%$ & $100 \%$ & $0 \%$ & $0 \%$ & $0 \%$ \\
\hline & & P7 & $30.8 \%$ & $23.1 \%$ & $38.5 \%$ & $0 \%$ & $7.7 \%$ \\
\hline & & P8 & $0 \%$ & $0 \%$ & $100 \%$ & $0 \%$ & $0 \%$ \\
\hline & & P9 & $100 \%$ & $0 \%$ & $0 \%$ & $0 \%$ & $0 \%$ \\
\hline & & $\mathrm{P} 10$ & $0 \%$ & $0 \%$ & $100 \%$ & $0 \%$ & $0 \%$ \\
\hline & & Other & $24 \%$ & $32 \%$ & $36 \%$ & $4 \%$ & $4 \%$ \\
\hline \multirow{6}{*}{5.2} & \multirow{6}{*}{$\begin{array}{l}\text { Staff know how to operate Unisa systems (e.g. } \\
\text { myUnisa, On-line library, Social Networks) }\end{array}$} & P6 & $0 \%$ & $0 \%$ & $0 \%$ & $100 \%$ & $0 \%$ \\
\hline & & P7 & $7.7 \%$ & $15.4 \%$ & $38.5 \%$ & $23.1 \%$ & $15.4 \%$ \\
\hline & & P8 & $0 \%$ & $0 \%$ & $0 \%$ & $100 \%$ & $0 \%$ \\
\hline & & P9 & $0 \%$ & $0 \%$ & $0 \%$ & $100 \%$ & $0 \%$ \\
\hline & & $\mathrm{P} 10$ & $0 \%$ & $0 \%$ & $100 \%$ & $0 \%$ & $0 \%$ \\
\hline & & Other & $12 \%$ & $16 \%$ & $24 \%$ & $36 \%$ & $12 \%$ \\
\hline \multirow{6}{*}{5.3} & \multirow{6}{*}{$\begin{array}{l}\text { Staff reckon that the region is ready to implement } \\
\text { e-learning }\end{array}$} & P6 & $0 \%$ & $0 \%$ & $100 \%$ & $0 \%$ & $0 \%$ \\
\hline & & P7 & $30.8 \%$ & $23.1 \%$ & $38.5 \%$ & $7.7 \%$ & $0 \%$ \\
\hline & & P8 & $0 \%$ & $0 \%$ & $0 \%$ & $100 \%$ & $0 \%$ \\
\hline & & P9 & $0 \%$ & $100 \%$ & $0 \%$ & $0 \%$ & $0 \%$ \\
\hline & & $\mathrm{P} 10$ & $0 \%$ & $0 \%$ & $0 \%$ & $100 \%$ & $0 \%$ \\
\hline & & Other & $20 \%$ & $28 \%$ & $32 \%$ & $16 \%$ & $4 \%$ \\
\hline
\end{tabular}

Staff were asked whether they think they have the requisite skills. As indicated in 5.2 in the table above most respondents indicated that they know how to operate Unisa systems however, since there is no clarity on the specific skills needed for supporting e-leaning implementation they are not sure of the appropriatness of their skills. In the same vein, questions were asked to determine the attitude of staff towards e-learning implementation. Generally, responses indicate that there were notable differences in attitude according to age, with the younger ones being positive about e-learning. However, there was no evident difference in terms of attitude and preparedness for e-learning noted in terms of gender, educational level and position. Essentially, there seemed to be a unanimous position from respondents that the lack of clarity on the scope and implications of e-learning has caused apprehension amongst staff generally. Because of this grey area the result is a largely negative orientation against the implementation of e-learning. 


\subsection{Perceived opportunities and challenges of e-learning}

Questions were asked to determine whether respondents perceived e-learning to have any opportunities or challenges. Whereas $40 \%$ agreed that e-learning is going to benefit students, $28 \%$ was not sure and $48 \%$ disagreed. In a statement that e-learning is likely to enhance tuition $60 \%$ gave a negative response.

Table 6. Anticipated opportunities and challenges

\begin{tabular}{|c|c|}
\hline Opportunitties & Challenges \\
\hline $\begin{array}{l}\text { The e-learning opportunity will add to a } \\
\text { civilised and developed society. } \\
\text { - Ideally, e-learning will enhance easy } \\
\text { access for students. } \\
\text { - E-learning will assist students to } \\
\text { familiarise themselves with computer } \\
\text { technology, a skill that is critical in the era } \\
\text { of globalisation. }\end{array}$ & $\begin{array}{l}\text { - Given that regional offices do not have adequate resources, the wider the } \\
\text { level of incompatibility the more it will be difficult to provide seamless } \\
\text { services. } \\
\text { - The lack of relevant skills for students most of whom are computer illiterate. } \\
\text { - The lack of technologically related competencies for staff is a serious } \\
\text { concern. } \\
\text { - Non-reliable network and electricity supply, disruptions are rampant and } \\
\text { unpredictable. } \\
\text { - The idea that e-learning and its implications is not clearly defined and } \\
\text { understood poses a serious challenge. }\end{array}$ \\
\hline
\end{tabular}

\subsection{Level of readiness for e-learning implementation}

The question seek to establish staff perception about the readiness of the region to implement e-learning. In response to the question $28 \%$ and $20 \%$ reckoned that the region is not ready with the former disagreeing strongly and the latter just disagreeing. About $32 \%$ of the respondents were not sure, whereas only $16 \%$ were of the impression that the region was ready, and a minimum of $4 \%$ agreed strongly to the notion of readiness. A significant observation was that most staff at managerial level were sceptical, cautious and not sure about the institutional readiness. Most junior staff alluded to the fact that they believe that its all systems go, that is, the institution is ready to implement e-learning.

\section{Conclusions and Recommendations}

The object of the paper was to examine readiness of Eastern Cape Regional Learning Centres in terms of their capability to implement e-learning as the dominant paradigm in the facilitation of learning. Overall, the results show that since the implementation of e-learning is still in its infancy there is still lack of clarity on the nature, goals and implications of elearning for the regional offices. For instance, there was a lack of correlation in staff responses when they were asked about institutional policies that inform e-learning. It emerged that most of them are not familiar with such policies which begs a question how are they going to implement principles that they are unfamiliar with. Similarly, there seem to be inappropriateness in the ratio between the number of staff versus the number of registered students in the region. The same applies to the number of computers available versus the number of students. Related to this is the issue of network systems and infrastructure, these were deemed inadequate and inapt which militates against the facilitation of e-learning. It emerged that since most computers are old and not functioning well, the region is not well placed to execute its mandate. It is unfortunate that the university did not consider the impact the old infrastructure will have on the new initiative. Given the socio-economic standing of the region, the shortage of staff as well as computers might have a negative effect on student support. It also emerged that the aptitude of most staff members is uncertain because there is no lever or yardstick for measuring one's competency because of the lack of clarity on the nature and implications of elearning. The study recommends that the University should establish synergy between new initiatives as well as students' realities, staff capability and regional infrastructure and socio-economic conditions.

\section{References}

Abu-Hassan-Assari, M.H. (2005). Adult learners and e-learning readiness: a case study. A paper presented at the European College Teaching \& Learning Conference, 13-17 June.

Agboola, A.K. (nd.). Assessing the awareness and perceptions of academic staff in using e-learning tools for instructional delivery in a post-secondary institution: a case study. The Public Sector Innovation Journal 11(3):1-12.

Ahmed, G.A.W. (2008). Modelling students' intention to adopt e-learning: a case study from Egypt. EJISDC. 34(1), 1-13. 
Assari, M.H. (2005). Adult learners and e-learning readiness: a case study. A paper presented at the European College Teaching \& Learning Conference, 13-17 June, Athens, Greece.

Aydin, C.H., \& Tasci, D. (2005). Measuring readiness for e-learning: reflections from an emerging country. Educational Technology \& Society 8(4), 244-257.

Buabeng-Andoh, C. (2012). Factors influencing teachers's adoption and integration of information communication technology into teaching: a review of literature. International Journal of Education and Development using Information and Communication Technology (IJEDICT 8(1), 136-155.

Carry, D., \& Willis, J. (2001). Technology and teacher education. Association for the Advancement of Computing in Education. Charlottesville, VA.

Clegg, S., Konrad, J. \& Tan, J. (2000). Preparing academic staff to use ICTs in support of student learning. The International Journal for Academic Development (5), 138-148.

Council on Higher Education: Annual Report. (2006-2007). Available: http://www.che.ac.za/sites/default/files/publications ICHE_Annual_report_06-07_complete_0.pdf.

Curran, C. (2004). Strategies for e-learning in universities. Research \& Occasional Paper Series: CSHE.7.04. Available: http://ishi.lib.berkeley.edu/cshe (2012).

Czerniewicz, L. (Ed.). (2007). ICTs and Higher Education in Africa. Status report on information and communication technologies (ICTs) in higher education in eight African countries. Available: http://www.cet.uct.ac.za/files/file/south\%20africa.pdf.

De Villiers, M.R. (2005). E-Learning artefacts: are they based on learning theory? Alternation 12 (1b), 345-371.

Dyson, L.E. (2004). Cultural issues in the adoption of information and communication technologies by indigenous Australians. Proceedings Cultural Attitudes Towards E-learning.

E-learning methodologies: A guide for designing and developing e-learning courses. (2011). Food and Agriculture Organisation of the United Nations (FAO): Rome, Italy.

Engelbrecht, E. (2003). A look at e-learning models: investigating their value for developing an e-learning strategy. Progressio 25(2), 8-47.

Faheeg, I.A. (2011). EFL students' readiness for e-learning: factors influencing e-learners' acceptance of the Backboard TM in a Saudi University. JALT CALL Journal, 7(1), 19-42.

Granic, A. Glavinic, V. \& Stankov, S. (2004). Usability evaluation methods for web-based educational systems. Available; http://www.ui4all.gr/workshop2004/files/ui4all_proceedings/adjunct/evaluation/28.pdf.

Hall, B. \& Snider, A. (2000). Glossary: The hottest buzz word in the industry. Learning 44(4), 85-104.

Higgins, A. (nd.). Creating a national e-learning strategy in the open learning environment: a New Zealand case study. An abridged version of the Report of the E-Learning Advisory Group entitled Highways and Pathways: exploring New Zealand e-learning opportunities. Available: http://www.col.org/pcf2/papers/higgins_1.pdf.

Kaur, K. \& Abas, Z.W. (2004). An assessment of e-learning readiness at the Open University Malaysia. Proceedings of the International Conference of e-learning. University of Quebec at Montreal, Canada, 22-23 June 2006.

Kinuthia, W. \& Dagada, R. (2006). E-learning delivery: exploratory study of ICT in higher education in South Africa. Paper presented at the Fourth Pan-Commonwealth Forum on Open Learning, Ocho Rios, Jamaica.

Lopez, C.T. (2007). Evaluating e-learning readiness in a health sciences higher education institution. Available: http://www.carlalopes.com/pubs/lopes IADIS 2007.pdf.

Pityana, N.B. (2005). Opening of the Johannesburg Regional Learning Service Centre. Johanneburg, Saturday 15 October.

Saekow, A. \& Samson, D. (2011). Assessing e-learning acceptance by university students in Thailand. International Journal of eEducation, e-Business, e-Management and e-Learning 1(2), 126-131.

Schreurs, J. Sammour, G. \& Ehlers, U. (nd.). E-learning readiness: analysis eHealth case study of e-learning readiness (ERA).

So, T. \& Swatman, M.C. (2006). e-Learning readiness of Hong Kong teachers.

Ssemugabi, S. \& De Villiers, M.R. (2010). Effectiveness of heuristic evaluation in usability evaluation of e-learning applications in higher education. School of Computing, University of South Africa. SACJ (45).

Tucker, D.T. (2007). A concerns-based approach to the adoption of web-based learning management systems. A dissertation submitted to the Graduate Faculty of North Carolina State University in partial fulfilment of the requirements for the Degree of Doctor of Education, Raleigh, North Carolina.

Tubaishat, A. \& Lansari, A. (2010-2011). Are students ready to adopt e-learning? A preliminary e-readiness study of a gulf University in the Gulf Region. International Journal of Information and Communication Technology Research 1(5): Available: http://www.esjournals.org.

University of South Africa. (2007). The Unisa 2015 strategic plan. Available at: www.unisa. ac.za. Accessed on 12/03/2010.

University of South Africa. (2012). The Organisational Architecture, Interim Report, May.

University of South Africa. (2012). UNISA Department of Information and Strategic Analysis (DISA).

University of South Africa. (2012). Regional Model.

University of South Africa. (2012). Revised Curriculum Policy.

University of South Africa. (2012). Tutor Model.

Unwin, T. (2008). Survey of e-learning in Africa: Based on Questionnaire Survey of people on the e-learning database in 2007. UNESCO.

Van Audenhove, L. (1999). South Africa's information society policy: an overview. Communication, Theory \& Research, Vol.25, Issue 12, 15-27.

Watkins, R. Leigh, D. \& Triner, D. (2004). Assessing readiness for e-learning. Performance Improvement Quarterly 17(4), 66-79. 